Case report

\title{
Guillain-Barré syndrome associated with COVID-19 infection: a case from the UK
}

\author{
May Yung Tiet 두, Nazar AlShaikh
}

Department of Neurology, University Hospitals of Leicester NHS Trust, Leicester, UK

\section{Correspondence to}

Dr May Yung Tiet;

m.tiet@doctors.org.uk

Accepted 1 July 2020

\section{SUMMARY}

Originating from Wuhan, China, COVID-19 has rapidly spread worldwide. Neurological manifestations are more commonly associated with severe COVID-19 infection. Guillain-Barré syndrome (GBS) is a rare immunemediated postinfectious neuropathy. It has been reported as a possible rare complication of COVID-19. We report a case of GBS associated with COVID-19 in the UK.

\section{BACKGROUND}

Severe acute respiratory syndrome coronavirus-2 (SARS-CoV-2) is typically associated with respiratory disease and fever. Originating from Wuhan, China, COVID-19 has rapidly spread worldwide. COVID-19 commonly presents with respiratory symptoms with mild clinical features in the majority of patients. The neurological manifestations of COVID-19 include headache, stroke, seizures, encephalitis, hypogeusia and neuralgia. ${ }^{1-3}$

Guillain-Barré syndrome (GBS) is a rare immunemediated postinfectious neuropathy typically leading to ascending weakness. It has been reported as a possible rare sequela of COVID-19, ${ }^{4-6}$ though the first reported case in Wuhan suggested a parainfectious presentation. ${ }^{7}$ We report a case of GBS associated with mild COVID-19 infection in the UK.

\section{CASE PRESENTATION}

A 49-year-old man of South Asian descent with no medical history, apart from sinusitis, presented with difficulty in mobilising. There was no recent travel history. He reported a 3 -week history of shortness of breath, headache and cough. He had completed two courses of antibiotics in view of his background of recurrent sinusitis. On initial presentation to the emergency department, he reported worsening cough and distal lower limb paraesthesia during the previous week, resulting in difficulty mobilising, requiring the use of a frame. He was apyrexial on presentation with a mild tachycardia of 109 , normal oxygen saturation of $99 \%$ on room air and haemodynamically stable. He had an elevated lactate on venous blood gas $(3.3 \mathrm{mmol} / \mathrm{L})$ and a mildly elevated C-reactive protein $(20 \mathrm{mg} / \mathrm{L})$. His white cell count, sodium, potassium and renal function and liver function were normal. His oropharyngeal swabs tested positive for SARS-CoV-2 on RT-PCR. His family members were self-isolating and had no symptoms of COVID-19. He had a mildly elevated creatine kinase (CK) of $589 \mathrm{IU} / \mathrm{L}$, which led to an initial diagnosis of viral myositis and was discharged.

The patient represented 3 days later with worsening lower limb paraesthesia and unable to mobilise due to ascending lower limb weakness. His repeat CK was normal (151 IU/L). Four days later, he had developed facial diplegia, weakness of Medical Research Council (MRC) Muscle Scale $1 / 5$ in his lower limbs, 3/5 proximal upper limbs and 2/5 distal upper limbs. He had distal reduced sensation to pinprick and vibration sense and was areflexic. There was no meningism, spinal cord sensory level, bladder or bowel involvement or dysautonomia. He developed dysaesthesia in his lower limbs which responded well to neuropathic medication, pregabalin.

\section{INVESTIGATIONS}

His cerebrospinal fluid (CSF) showed cytoalbuminologic dissociation (protein $>1.25 \mathrm{~g} / \mathrm{L}$, white cell count $\left.1 \times 10^{6} / \mathrm{L}\right)$. His CSF was negative for SARS-CoV-2. He continued to test positive for SARS-CoV-2 on oropharyngeal swabs for 4 weeks after initial presentation. His neurophysiology studies showed absent sensory response of the median nerve (table 1A) and severe slowing of motor responses of the median and ulnar nerve with reduced amplitude (table 1B). He had severe neurogenic firing with normal motor units, without spontaneous activity, on electromyography (table $1 \mathrm{C}$ ), indicating a demyelinating polyneuropathy. Meeting all domains of the Brighton criteria, ${ }^{8}$ a diagnosis of GBS was confirmed.

\section{TREATMENT}

During the initial week of admission, the patient was monitored in intensive care and required a nasogastric tube for feeding due to swallowing difficulties, without respiratory dysfunction. $\mathrm{He}$ received intravenous immunoglobulin (IVIG) 0.4 $\mathrm{g} / \mathrm{kg}$ daily for 5 days and his symptoms stabilised, avoiding the requirement of intubation.

\section{OUTCOME AND FOLLOW-UP}

The patient's motor symptoms began to improve within the first week of IVIG administration. Four weeks later, the patient no longer had facial diplegia and his motor strength had improved to $4 / 5$ proximally, $3 / 5$ distally and lower limbs $3 / 5$. Eleven weeks later, after receiving neurorehabilitation and optimisation of neuropathic medications, the patient was able to mobilise unassisted. 


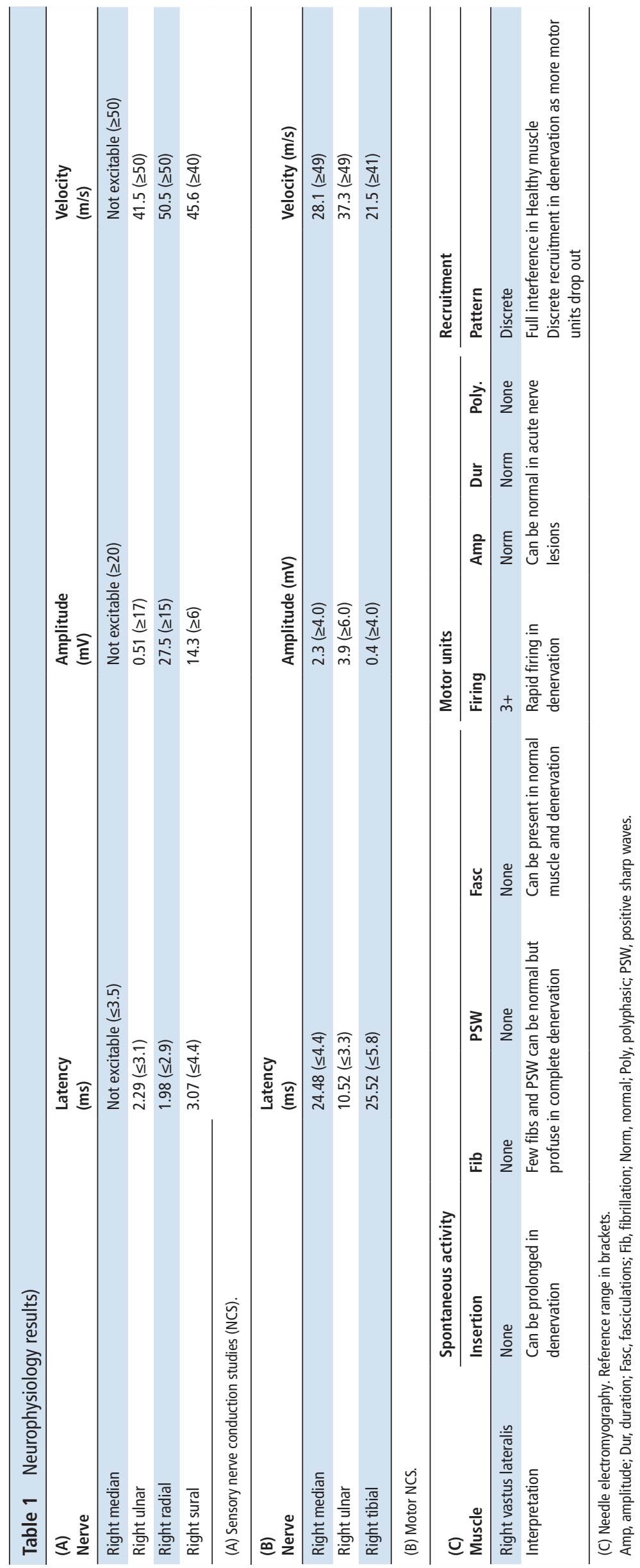

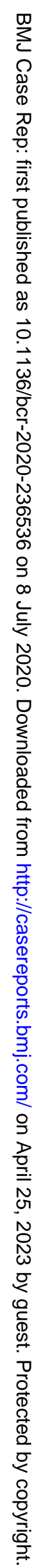


Patient's perspective

A week or so prior to the lockdown, I came down with sinusitis which for me is a yearly occurrence. Nonetheless, I followed the governments suggested self-isolation protocol by remaining in my room upstairs for the couple of weeks period as my brother and father are highly vulnerable to catching infections due to their health conditions.

Towards the end of my isolation, my legs and arms began to become stiff and painful to move, making an everyday task such as walking difficult. As a person who enjoys weekly sessions of badminton and gym workouts, this sudden inability to move my limbs came as an utter shock as I never imagined something like this happening to myself, as I feel that I am quite fit and active.

On the 8th of April I called an ambulance in the morning and proceeded to lug myself downstairs slowly in excruciating pain, after which I was taken to A\&E for a check. After my examination I was discharged with a bit of treatment. When being collected from the hospital by a family member, I was unable to stand up from the wheelchair I was in and get into the car. Two security guards had to haul me in.

On arrival home, I got out of the car with a Zimmer frame and only meters away from the door, my legs lost all strength and gave way causing me to collapse in the driveway. I spent a few hours with the help of the family trying to get up and into the house but I was not able to get up for myself and as a result my family could not lift my dead weight. As a result of this, an ambulance was called out and took me to A\&E for me to only be sent home again, with no explanation to the loss of strength and mobility of my limbs.

As my mobility condition worsened, I had no choice but to sleep and live downstairs in the living room which is adjacent to my brother's room and along with my father who also sleeps downstairs. This was a big concern for me, as I still had signs of an infection. Throughout the next 2 days my mobility further worsened, meaning I was unable to sit up from lying in bed, my ability to grasp objects in my hand had lessened, I was not able to stand up from a sitting position and many more.

These all increased the difficulty of performing normal tasks especially going to the toilet, which had to be done with the help of my family yet again. My family were forced to lift me out of bed and wrestle me onto a commode before I could proceed to be taken to the toilet. Where the process had to be reversed to get onto the toilet seat. Once completed, as before, the strenuous task of getting back to bed had to be achieved.

On the following day, due to a fall, another ambulance had been called in which claims of me potentially having COVID-19 had been made. And yet again was forced in a self-isolation. Despite this I was still unable to perform tasks, so my family had to come to my aid with gloves and masks on.

On the early morning hours of the 11th of April, I awoke with extreme discomfort, weakness and a complete loss of energy. I rang the 111-advice service in which the verbal examination indicated that I required hospital support. And the 111 workers requested an ambulance to be sent out. In the wait of the ambulance I began to lose consciousness, fortunately my family were able to keep me aware. The ambulance arrived only moments after. In which it took four personnel to assist me in getting out of bed and onto the wheelchair.

I was examined for the third time and was diagnosed with the Coronavirus. Doctors claimed that the virus had attacked my nervous system and had damaged it. This became a concern

Continued

\section{Patient's perspective Continued}

for the doctors, as prospects that the nerves in my respiratory system could also be attacked, reducing my own ability to breathe. As a precaution I was transferred into the ICU.

Over the coming weeks numerous tests and treatments were administered to help cure me. With recent news that my condition is noted as new and unseen. I have written this passage depicting my struggles.

I am still in hospital and am in the process of a recovery, even though it may be a slow one. This experience has been extremely frightening with the constant apprehension that my life might never be the same again. Among the fight it has also been an extremely painful and disconcerting process as I have never experienced any illness first-hand in my entire life.

My utmost gratitude goes towards those who have helped me and continue to help me in my recovery of the illness especially all the workers of the NHS.

\section{DISCUSSION}

The first reported case of COVID-19-associated GBS was reported from Wuhan as a suspected parainfectious disease, as the patient developed COVID-19 symptoms 7 days after the onset of GBS symptoms. ${ }^{7}$ Here, we have presented a patient from the UK who developed GBS as a likely postinfectious complication 3 weeks after the initial onset of infectious symptoms. Our case supports increasing numbers of reports of COVID-19-associated autoimmune neuropathies, ${ }^{56}$ including the Miller-Fisher variant of GBS. ${ }^{9}$ As with reports from Italy, our patient was highly responsive to immunoglobulin therapy, ${ }^{10}$ emphasising the importance of early recognition and treatment.

Toscano et al report five cases of COVID-19 who developed GBS 5 to 10 days post infection; all five cases had negative PCR for SARS-CoV-2 in CSF. Our patient remained positive for SARS-CoV-2 for approximately 7 weeks post onset of initial COVID-19 symptoms, supporting previous reports of RT-PCR remaining positive in patients who have fully recovered from COVID-19, which raises questions about the duration of viral shedding. ${ }^{11}$ Neurological manifestations of COVID-19 is often associated with severe acute respiratory distress syndrome but our patient presented with neurological sequelae following mild COVID-19 symptoms. Despite neurological sequelae, RNA may not be detected in $\mathrm{CSF}^{4}{ }^{12}$ as in

\section{Learning points}

- Neurological complications are more commonly associated with severe COVID-19 symptoms but postinfectious neuropathies can occur even following mild COVID-19 infections.

- Guillain-Barré syndrome (GBS) is a rare but serious complication of severe acute respiratory syndrome coronavirus-2 (SARS-CoV-2) infection and should not be overlooked as viral-associated myositis. Early reports suggest a positive response to intravenous immunoglobulin therapy.

- SARS-CoV-2 PCR may be negative in cerebrospinal fluid but SARS-CoV-2 PCR from oropharyngeal swabs can remain positive for several weeks after initial COVID-19 symptoms.

- Early recognition of COVID-19-associated GBS is vital to initiate immunoglobulin therapy. 
our case; though there has been a reported case of encephalitis with SARS-CoV-2 detected in CSF but not nasopharyngeal swabs. ${ }^{12}$ GBS has severe consequences and early recognition is vital to monitor for loss of ambulation and initiation of immunoglobulin treatment. Patients presenting with paresthesia and difficulty in mobilising after COVID-19 symptoms should not be overlooked as viral-associated myositis. GBS should be considered as a potential rare but serious complication weeks after initial COVID-19 infection.

Contributors MYT drafted and finalised the manuscript. NMOAAS edited the manuscript.

Funding The authors have not declared a specific grant for this research from any funding agency in the public, commercial or not-for-profit sectors.

Competing interests None declared.

Patient consent for publication Obtained.

Provenance and peer review Not commissioned; externally peer reviewed.

This article is made freely available for use in accordance with BMJ's website terms and conditions for the duration of the covid-19 pandemic or until otherwise determined by BMJ. You may use, download and print the article for any lawful, non-commercial purpose (including text and data mining) provided that all copyright notices and trade marks are retained.

ORCID iD
May Yung Tiet http://orcid.org/0000-0002-3183-7087

\section{REFERENCES}

1 Mao L, Wang M, Chen S, et al. Neurological manifestations of hospitalized patients with COVID-19 in Wuhan, China: a retrospective case series study. SSRN Journal 2020.

2 Zhou L, Zhang M, Wang J, Gao J, et al. Sars-Cov-2: underestimated damage to nervous system. Travel Med Infect Dis 2020;101642:101642.

3 Helms J, Kremer S, Merdji H, et al. Neurologic features in severe SARS-CoV-2 infection. N Engl I Med Overseas Ed 2020;382:2268-70.

4 Toscano G, Palmerini F, Ravaglia S, et al. Guillain-Barré syndrome associated with SARS-COV-2 TO. NEJM, 2020.

5 Riva N, Russo T, Falzone YM, et al. Post-Infectious Guillain-Barré syndrome related to SARS-CoV-2 infection: a case report. J Neurol 2020:1-3.

6 Chan JL, Ebadi H, Sarna JR. Guillain-Barré syndrome with facial diplegia related to SARS-CoV-2 infection. Can J Neurol Sci 2020:1-3.

7 Zhao H, Shen D, Zhou H, et al. Guillain-Barré syndrome associated with SARS-CoV-2 infection: causality or coincidence? Lancet Neurol 2020;19:383-4.

8 Fokke C, van den Berg B, Drenthen J, et al. Diagnosis of Guillain-Barré syndrome and validation of Brighton criteria. Brain 2014;137:33-43.

9 Lin E. COVID-19-Associated Miller Fisher Syndrome : MRI Findings, 2020: 1-3.

10 Andrea A, Luana B, Silvia DM, et al. New clinical manifestation of COVID-19 related Guillain-Barrè syndrome highly responsive to intravenous immunoglobulins: two Italian cases. Neurol Sci 2020:1-4.

11 Lan L, Xu D, Ye G, et al. Positive RT-PCR test results in patients recovered from COVID-19. JAMA 2020;323:1502-4.

12 Moriguchi T, Harii N, Goto J, et al. A first case of meningitis/encephalitis associated with SARS-Coronavirus-2. Int J Infect Dis 2020;94:55-8.

Copyright 2020 BMJ Publishing Group. All rights reserved. For permission to reuse any of this content visit https://www.bmj.com/company/products-services/rights-and-licensing/permissions/

BMJ Case Report Fellows may re-use this article for personal use and teaching without any further permission.

Become a Fellow of BMJ Case Reports today and you can:

- Submit as many cases as you like

- Enjoy fast sympathetic peer review and rapid publication of accepted articles

- Access all the published articles

Re-use any of the published material for personal use and teaching without further permission

Customer Service

If you have any further queries about your subscription, please contact our customer services team on +44 (0) 2071111105 or via email at support@bmj.com.

Visit casereports.bmj.com for more articles like this and to become a Fellow 